\title{
Current status of plant metabolite-based fabrication of copper/copper oxide nanoparticles and their applications: a review
}

\author{
Khwaja Salahuddin Siddiqi ${ }^{1}$ and Azamal Husen ${ }^{2^{*}}$ (I)
}

\begin{abstract}
Since green mode of nanoparticles (NPs) synthesis is simple, advantageous and environment friendly relative to chemical and physical procedures, various plant species have been used to fabricate copper and copper oxide nanoparticles (Cu/CuO-NPs) owing to the presence of phytochemicals which often act as capping as well as stabilizing agent. These $\mathrm{Cu} / \mathrm{CuO}-\mathrm{NPs}$ are highly stable and used in the degradation of organic dyes like methylene blue and reduction of organic compounds such as phenols. They are also used as antibacterial, antioxidant and antifungal agent due to their cytotoxicity. They are also examined for agricultural crops growth and productivity. Cu-NPs increased the root and shoot growth of mung bean. In wheat plants, these particles reduced shoot growth; and enhanced the grain yield and stress tolerance through starch degradation. Similarly, CuO-NPs treated seedlings have shown reduced chlorophyll, carotenoid and sugar content, whereas proline and anthocyanins were increased in Brassica rapa seedlings. Overall, this review presents the recent understanding of plant-mediated Cu and CuONPs fabrication and their application in biomedicine, environmental remediation and agricultural practices. A comparison of the traditional/conventional method of fabrication of NPs with those of green protocols has also been made. Some misconception of copper chemistry has also been critically discussed in terms of oxidation and reduction reactions.
\end{abstract}

Keywords: Cu/CuO NPs, Biogenic synthesis, Biomedical, Crop growth, Applications

\section{Introduction}

Recent advancement in nanotechnology has accelerated our interest in designing nano sized particles of desired shape and size. Since their property changes with morphology they have been used in various areas of medicine, agriculture and environmental remediation [1-4]. The 'green synthesis' of nanoparticles (NPs) using plant is advantageous over chemical, physical and or microbial synthesis as it removes the complicated protocol; and can also meet the large-scale production requirement. Further,

* Correspondence: adroot92@yahoo.co.in

${ }^{2}$ Wolaita Sodo University, P.O. Box: 138, Wolaita, Ethiopia

Full list of author information is available at the end of the article the deliberate synthesis of NPs by chemical/physical methods require fairly large amount of toxic chemicals which also leave undesirable materials that pollute the environment. Disposal of such by products is also hazardous to human beings. Besides the use of expensive chemicals, the NPs thus fabricated are not capped/coated, and therefore they are not protected and are relatively less stable than those produced by plant-based materials. In order to protect these nanomaterials (NMs) they are coated with polyethylene glycol like polymers. Methods using lower and higher plant materials and their products; fungi and sometimes microorganisms for NPs fabrication are ecofriendly (Figs. 1 and 2) [2-5]. Since these materials are 


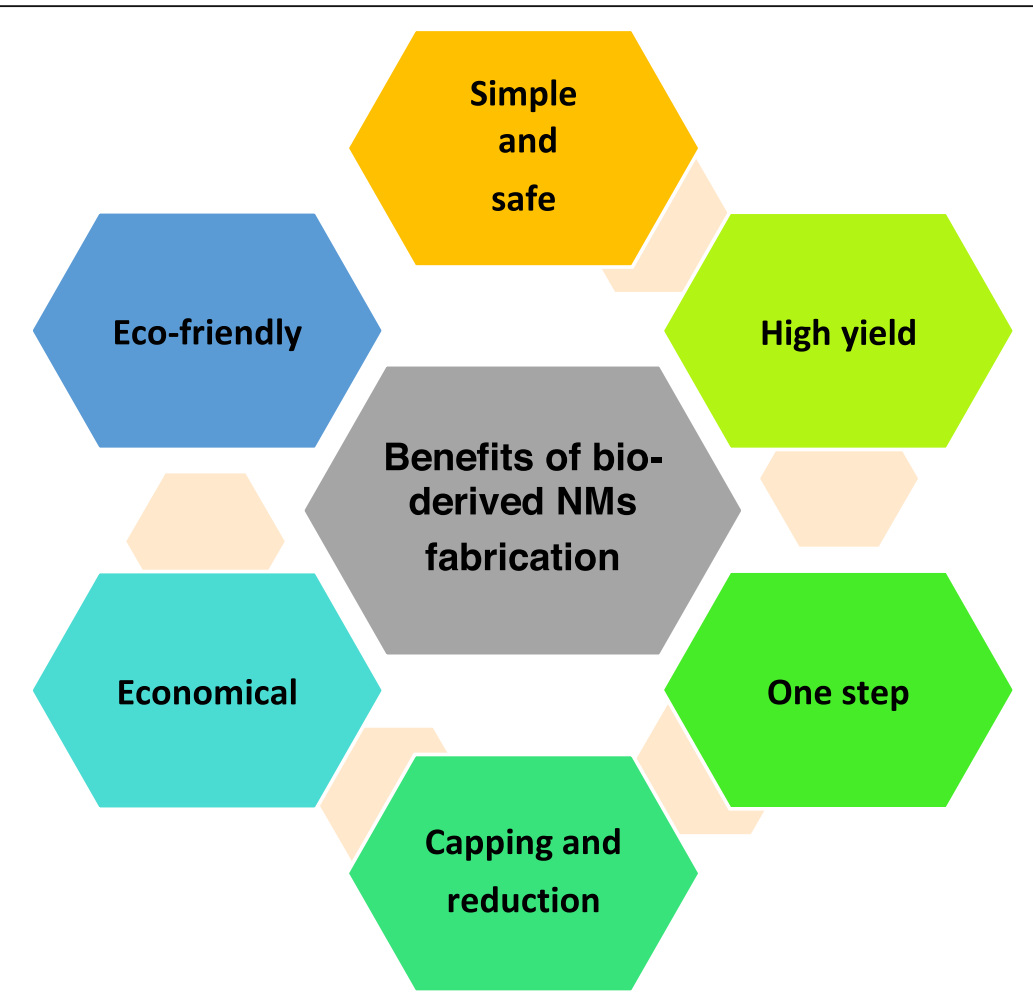

Fig. 1 Benefits of bio-derived fabrication/green synthesis of nanoparticles over chemical and physical procedures

easily available and do not require organic solvent as reaction medium, they are easy to handle and economical. In major cases the NMs thus synthesized are capped by biomolecules like phenols, tannin, flavonoids and ascorbate present in the plant materials. They enhance stability of NPs and also prevent their interaction with atmospheric oxygen. These NMs are thus not oxidized and can be kept for long period of time without undergoing any change in their properties. Green synthetic methods make use of many waste materials like banana peels, lemon rind, dried leaves of medicinal plants and algae etc. The precursor even in crude form may react with these materials to produce NPs. The noble metal NPs for example silver, gold, platinum and their alloys have been frequently biosynthesized by various workers [6-12]. Among the coinage metal NPs, copper nanoparticles (Cu-NPs) are of great interest due to their low cost, easy availability and high electrical conductivity [1315]. Borkow and Gabbay [16] and Zheng et al. [17] have reported that the copper ions are used as pesticides, fungicides and fertilizers. Copper oxide $(\mathrm{CuO})$ is also a cheaper material in comparison to silver/gold and can easily be mixed with polymers due to their stability [18]. Recently, Din et al. [19] have discussed the synthesis and characterization of cupric-oxide nanoparticles $(\mathrm{CuO}-\mathrm{NPs})$ together with their application as antioxidant, antibacterial and antifungal agent.
In general, $\mathrm{Cu}-\mathrm{NPs}$ are used as an antimicrobial, antioxidant, antidiabetic, anti-inflammatory and antifouling agent when integrated in coatings, plastics and textiles [20-23]. They also find application in heat transfer fluids, sensors, e-sensitized solar cells, lithium ion batteries, gas -sensing, heterogeneous catalysis and as anticancer agent [24-28].

Based on the current information, the present review unfolds the protocol of plant-mediated bio-fabrication of $\mathrm{Cu}-\mathrm{NPs} / \mathrm{CuO}-\mathrm{NPs}$ followed by their characterization and application in different areas. Attempt has also been made to enlist the impact of NPs on crops as growth promoter and the effect of size of NPs on their efficiency as catalyst and antibacterial agent.

\section{Fabrication of cu-NPs/CuO-NPs Cu-NPs}

Synthesis of spherical Cu-NPs of $23 \pm 1.10 \mathrm{~nm}$ from aqueous flower extract of Millettia pinnata and their characterization by ultraviolet-visible spectroscopy (UVVis), scanning electron microscopy (SEM), transmision electron microscopy (TEM), $x$-ray diffraction (XRD), Fourier transform infrared spectroscopy (FTIR) and selected area electron diffraction (SAED) has been reported by Thiruvengadam et al. [21]. UV-Vis study has confirmed the reduction of copper acetate to $\mathrm{Cu}-\mathrm{NPs}$. The maximum absorption was recorded at $384 \mathrm{~nm}$ which confirmed the 


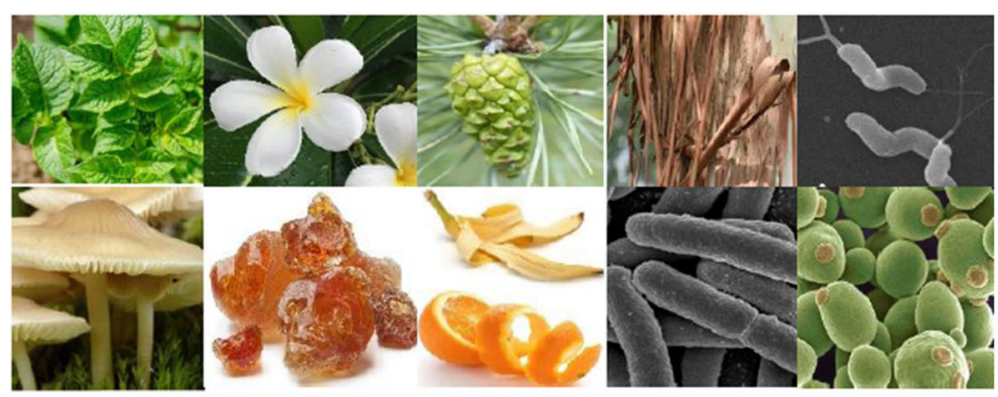

Plants and their products, fungus and microorganism

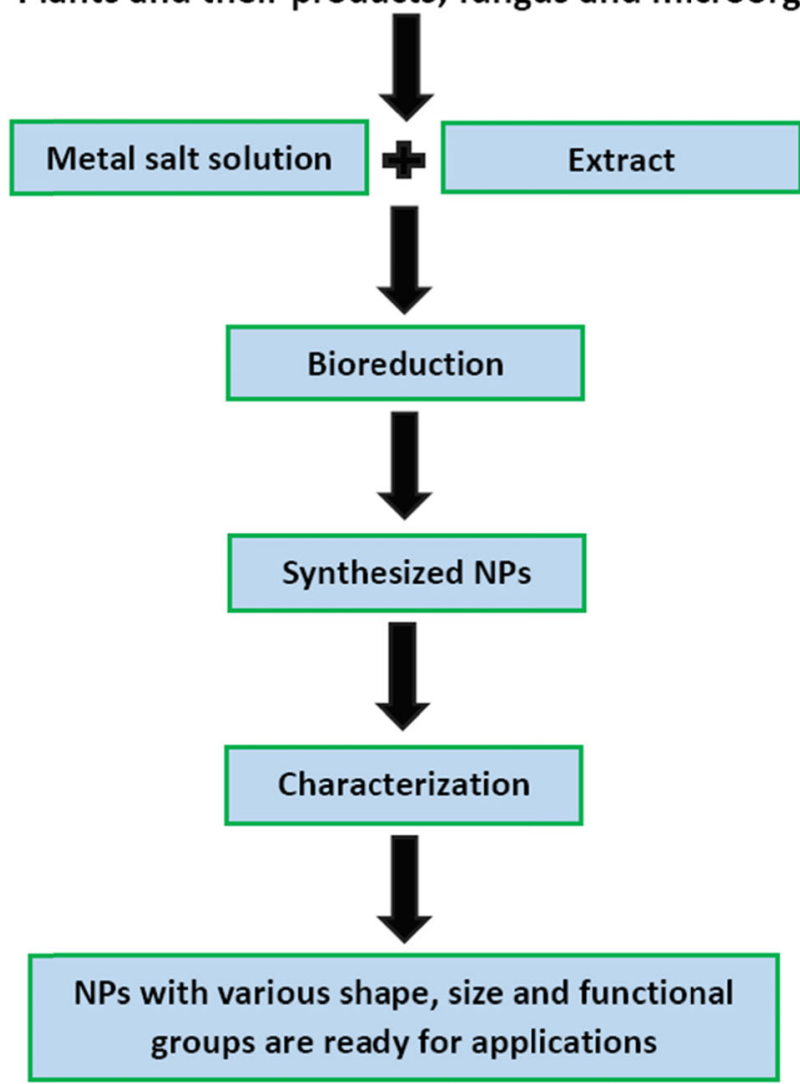

Fig. 2 Detailed scheme of bio-derived fabrication/green synthesis of nanoparticlesusing lower/higher plant materials and their products; fungus and microorganisms

surface plasmon resonance (SPR) of the NPs. Their FTIR spectrum indicated the presence of proteins, acids, flavonoids, polyphenols, carboxylic acid and alkaloids which reduced the copper ions into $\mathrm{Cu}-\mathrm{NPs}$.

$\mathrm{Cu}-\mathrm{NPs}$ of $50-250 \mathrm{~nm}$ diameters have been fabricated from Magnolia kobus leaf extract at room temperature [29]. Most of these NPs were spherical in shape and their formation was confirmed from UV-Vis spectrum exhibiting a peak at $560 \mathrm{~nm}$. As the concentration of $\mathrm{Cu}-\mathrm{NPs}$ increases the intensity of absorption peak measured at $560 \mathrm{~nm}$ also increases. It has also been observed that with increase in temperature yield of the $\mathrm{Cu}$-NPs increases. However, complete conversion was achieved at about $90-95^{\circ} \mathrm{C}$. It was observed that when concentration of Magnolia leaf extract was increased up to $20 \%$, smaller and spherical NPs were formed [30]. It is suggested that organic molecules/metabolites acting as capping agents also cause aggregation of NPs but it takes long time. Energy-dispersive x-ray (EDX) spectra showed signals for copper along with oxygen and carbon. Signals for other elements may not be due to biomolecules adhering to the surface of $\mathrm{Cu}-\mathrm{NPs}$ but they may be due to impurity present in the colloidal mixture of NPs and leaf extract. It has been noted that chemically fabricated NPs were air oxidized while those synthesized by Magnolia leaf extract were stable for more than 30 days [30]. It is because the biomolecules acting as capping agent protect the $\mathrm{Cu}-\mathrm{NPs}$ from oxidation by air. 
Kulkarni et al. [31] have examined the fabrication of $\mathrm{Cu}-\mathrm{NPs}$ from copper sulfate and Eucalyptus sp. leaf extract at room temperature. A slight change in $\mathrm{pH}$ of the copper sulfate solution from 2.16 to 2.83 was observed when leaf extract at $\mathrm{pH} 6.96$ was added followed by a change in colour of the resulting mixture which showed absorption at $572 \mathrm{~nm}$ in its Uv-Vis spectrum. FTIR spectrum of the $\mathrm{Cu}$-NPs showed the presence of phenol, amine, amino acid and flavonoids. It has been suggested that the biomolecules present in the eucalyptus leaf extract act both as reducing and capping agent. The NPs were highly crystalline with face centred cubic (FCC) structure. Their average size was found to be $38.62 \mathrm{~nm}$. It is worth observing that the concentration and $\mathrm{pH}$ of the reducing agent is mainly responsible for the production of NPs.

Biosynthesis of $\mathrm{Cu}$-NPs from leaf broth of Azadirachta indica and the influence of concentration of precursor salt, concentration of leaf broth, temperature and $\mathrm{pH}$ of the medium were reported on the conversion rate of $\mathrm{Cu}$ NPs [32] which are similar to those found above [31].

Ultrasmall $\mathrm{Cu}$-NPsof $2.90 \pm 0.64 \mathrm{~nm}$ diameter have been synthesized from lemongrass tea by one pot method [33]. Although, colour of the mixture containing both the $\mathrm{Cu}-\mathrm{NPs}$ and lemongrass was yellow it did not exhibit any absorption in the UV-Vis region (350-950 $\mathrm{nm})$. It has been ascribed to extremely small size of $\mathrm{Cu}$ NPs which are devoid of surface plasmon resonance [34, 35]. It is strange and unusual for NPs to exhibit colour but no absorption. Generally, a sharp peak is observed in 560 to $570 \mathrm{~nm}$ region for $\mathrm{Cu}-\mathrm{NPs}$ if they are larger than $5 \mathrm{~nm}$ [34-36]. Their IR spectra showed the presence of polyphenols, proteins and carbohydrate [37, 38] as reducing agents. SEM and TEM images showed the presence of finely divided and dispersed Cu-NPs. However, they were not found to be oxidized either to cuprous oxide or cupric oxide which is quite obvious because in presence of reducing agents oxidation cannot occur. It has been observed that polyethyleneglycol or polyvinyl pyr olidone can also prevent the NPs from oxidation and aggregation [39-41].

$\mathrm{Cu}-\mathrm{NPs}$ synthesized using aqueous leaf extract of henna (Lawsonia inermis) showed an absorption peak at $570 \mathrm{~nm}$ which is the signature peak of CuO-NPs [42]. Blue copper sulfate absorbs at $810 \mathrm{~nm}$ but $\mathrm{Cu}$-NPs are reddish brown if all copper ions have been reduced to $\mathrm{NPs}$. It has been reported that $\mathrm{Cu}-\mathrm{NPs}$ are surrounded by a thin film of copper oxide $\left(\mathrm{CuO}\right.$ and $\left.\mathrm{Cu}_{2} \mathrm{O}\right)$ which is characterized by absorption at $800 \mathrm{~nm}$ [43]. It may be due to the presence of already oxidized copper sulfate present as impurity because in solution it cannot be oxidized unless it is heated in open at about $900{ }^{\circ} \mathrm{C} . \mathrm{Cu}$ NPs are efficiently formed at $\mathrm{pH} 11$. Perhaps reduction of copper ions is facilitated in highly alkaline medium as the lawsones are stabilized at higher $\mathrm{pH}$. Electrical conductivity of calcined $\mathrm{Cu}$-NPs was enhanced because all particles come closer as a result of which the mobility of electrons increases [44]. Authors have found that the absorption of $\mathrm{Cu}-\mathrm{NPsat} 570 \mathrm{~nm}$ was lost and a new peak appeared at $285 \mathrm{~nm}$ when $\mathrm{Cu}-\mathrm{NPs}$ were calcined. It is highly improbable for a calcined material to absorb in UV region of spectrum. It may be quite likely that the spectrum was not carefully run otherwise any transition metal or its oxide will not show any absorption in UV range. Their interpretation of electronic transition from inner to the outermost shell of copper [45] is highly unlikely because such situation occurs only when copper ion forms a coordination compound with a very strong ligand and forces one of the $3 \mathrm{~d}^{9}$ electrons to be transferred to the outer $4 \mathrm{~d}$ orbital. Since there are no copper ions this peak at $284 \mathrm{~nm}$ is most likely to be due to some impurity. SEM and EDAX showed agglomerated spherical $\mathrm{Cu}$-NPs. The suggestion that $\mathrm{Cu}-\mathrm{NPs}$ are oxidized to $\mathrm{CuO}$ on exposure to air is author's lack of knowledge of copper chemistry. If the $\mathrm{Cu}-\mathrm{NPs}$ are exposed to air they will form $\mathrm{CuSO}_{4}$ which is evidenced by a distinct blue colour on its surface but it is not oxidized to copper oxides.

Biogenic synthesis and characterization of $\mathrm{Cu}-\mathrm{NPs}$ from Citrus medica juice has been reported [46]. UV-Vis spectrum showed absorption peak at $631 \mathrm{~nm}$ which has been taken as an evidence for the formation of $\mathrm{Cu}-\mathrm{NPs}$. Since the reduction reaction was carried out in an aluminum vessel instead of a glass vessel some fraction of aluminum would have dissolved in the citron juice. Blue $\mathrm{CuSO}_{4}$ solution turned reddish brown due to formation of $\mathrm{Cu}_{2} \mathrm{SO}_{4}$ after the addition of citron juice, followed by deposition of shiny brown precipitate on the wall of aluminum vessel. It is suggested that a more reactive metal displaces a less reactive metal from its compound in aqueous medium [47] according to the following reaction.

$$
2 \mathrm{Al}_{(\mathrm{s})}+3 \mathrm{Cu}_{2} \mathrm{SO}_{4}(\mathrm{aq}) \rightarrow \quad 6 \mathrm{Cu}(\mathrm{s})+\mathrm{Al}_{2}\left(\mathrm{SO}_{4}\right)_{3}(\mathrm{aq})
$$

Also, it has been stated that usually, copper cannot be obtained through the reduction of $\mathrm{CuSO}_{4}$ in water [48]. The reduction stops at $\mathrm{Cu}_{2} \mathrm{O}$ stage due to aggregation of water molecules around copper core [49]. However, reduction of $\mathrm{CuSO}_{4}$ to $\mathrm{Cu}_{2} \mathrm{O}$ is highly improbable because it is unstable and quickly oxidized to $\mathrm{CuSO}_{4}$ again. Addition of a surfactant at this stage yields $\mathrm{Cu}$-NPs. Size of $\mathrm{Cu}$-NPs ranged between 10 and $60 \mathrm{~nm}$ although average size was found to be $33 \mathrm{~nm}$.

Fabrication of $\mathrm{Cu}$-NPs from aqueous leaf extract of Euphorbia esula has been reported [50]. Catalytic activity of the NPs for the reduction of 4-nitrophenol and ligand free Ullmann-coupling reaction has also been 
investigated. Phenols and flavonoids in the leaf extract of E. esula act as reducing and capping agent for $\mathrm{Cu}-\mathrm{NPs}$. It has been shown from TEM images and size distribution studies that $\mathrm{Cu}-\mathrm{NPs}$ are of $20-110 \mathrm{~nm}$ diameter. However, particles with $40 \mathrm{~nm}$ diameter are in abundance with FCC structure. Catalytic activity of $\mathrm{Cu}-\mathrm{NPs}$ for the reduction of 4-nitrophenol to 4-aminophenol has been studied in presence $\mathrm{NaBH}_{4}$. The reduction of nitrophenol to aminophenol was ascertained from a change in colour from light yellow to deep yellow followed by shift of absorption from 317 to $403 \mathrm{~nm}$ due to the formation of nitrophenolate ions. When $\mathrm{Cu}$-NPs were added, the solution became colourless after $580 \mathrm{~s}$ with the appearance of a new peak at $300 \mathrm{~nm}$, as a result of the formation of 4-amino phenol.

Fabrication of $\mathrm{Cu}-\mathrm{NPs}$ of $15-20 \mathrm{~nm}$ from aqueous peel extract of Punica granatum has been achieved which also acts as reducing as well as capping agent [51]. The UV-Vis spectrum of $\mathrm{Cu}-\mathrm{NPs}$ practically shows a flat line without any absorption in the vicinity of $500-700 \mathrm{~nm}$. Although there is a very faint elevation at 585 it cannot be considered as an absorption corresponding to $\mathrm{Cu}-\mathrm{NPs}$ [52]. The other absorptions below $400 \mathrm{~nm}$ have been assigned to the presence of proteins, enzymes and flavonoids. Since the mixture containing extract and $\mathrm{CuSO}_{4}$ was heated at $80^{\circ} \mathrm{C}$, the enzymes would have certainly denatured and therefore the absorption in the above region may be only due to other stable phytochemicals present in the extract.
Activated carbon microfibers (ACF) coated with copper and stabilized with sodium dodecyl sulphate have been used as carrier for copper transport [53]. It was calcined at $350{ }^{\circ} \mathrm{C}$ to $\mathrm{CuO}-\mathrm{ACF}$ and finally reduced in a current of hydrogen to generate $\mathrm{Cu}$ - $\mathrm{ACF}$ carbon nanofibers (CNF). They were then grown on $\mathrm{Cu}-\mathrm{ACF}$ to produce $\mathrm{Cu}-\mathrm{CNF} / \mathrm{ACF}$ [53]. The Cicer arietinum plant treated with $\mathrm{Cu}-\mathrm{CNF}$ grew well relative to the untreated plant. Shoots of the plant showed the presence of $\mathrm{Cu}$ CNF. Presence of copper and carbon fibers was seen in the shoot of plant. It is supposed to be translocated via xylem of the plant. This material is a source of transport of copper as a micronutrient. $\mathrm{Cu}-\mathrm{NP}$ released is thought to be converted to $\mathrm{Cu}^{2+}$ ions and $\mathrm{Cu}-\mathrm{CNF}$ is considered as growth stimulant to plants. Further details of various plant species and their parts used in $\mathrm{Cu}-\mathrm{NPs}$ synthesis and other associated activities are presented in Table 1.

\section{CuO-NPs}

Biosynthesis of $\mathrm{CuO}-\mathrm{NPs}$ from gum karaya has been reported [54]. A mixture of $\mathrm{CuCl}_{2}$ and gum in aqueous solution was made alkaline and heated at $75^{\circ} \mathrm{C}$ with continuous stirring. Blue copper chloride turned black after $1 \mathrm{~h}$ which was separated as black powder. $\mathrm{CuO}$ NPs were deposited on the surface of gum karaya perhaps due to their affinity for gum. XRD analysis showed the presence of crystalline CuO-NPs scattered all over the gum matrix which is identical to those reported earlier [55]. FTIR spectrum showed peaks in the lower region of the spectrum corresponding to $\mathrm{Cu}-\mathrm{O}$ stretching

Table 1 Recent studies (during 2018-19) on plant-mediated synthesis of Cu-NPs, their morphology, and various applications

\begin{tabular}{|c|c|c|c|c|c|}
\hline Plant & $\begin{array}{l}\text { Part of plant } \\
\text { used }\end{array}$ & Active compounds & Shape and size & Various applications & $\overline{\text { Key references }}$ \\
\hline Azadirachta indica & Leaf & $\begin{array}{l}\text { Flavonoids, terpenoids } \\
\text { and polyphenols }\end{array}$ & $\begin{array}{l}\text { Crystalline, } \\
\text { cubical; } \sim 48 \mathrm{~nm}\end{array}$ & - & [32] \\
\hline Cissus arnotiana & Leaf & Biomolecules & Spherical; 60-90 nm & $\begin{array}{l}\text { Antibacterial and antioxidant } \\
\text { activities }\end{array}$ & [121] \\
\hline Green and black tea & Leaf & Flavonoids and phenols & Spherical; 26-40 nm & $\begin{array}{l}\text { Aflatoxins adsorbent; } \\
\text { antibacterial and antifungal } \\
\text { activities }\end{array}$ & [122] \\
\hline Eichhornia crassipes & Flower & Lawsone and phenols & Spherical; 12-15 nm & $\begin{array}{l}\text { Detection of hazardous } \\
\text { hydrogen peroxide }\end{array}$ & [123] \\
\hline Falcaria vulgaris & Leaf & - & Spherical; $20 \mathrm{~nm}$ & $\begin{array}{l}\text { Cutaneous wound healing potentials } \\
\text { without any cytotoxicity; antioxidant, } \\
\text { antifungal and antibacterial activites }\end{array}$ & [124] \\
\hline Millettia pinnata, & Flower & $\begin{array}{l}\text { Proteins, acids, favonoids, } \\
\text { polyphenols, carboxylic } \\
\text { acid and alkaloids }\end{array}$ & Spherical; $23 \pm 1.10 \mathrm{~nm}$ & $\begin{array}{l}\text { Antioxidant, antibacterial, antidiabetic } \\
\text { and anti-inflammatory agents }\end{array}$ & {$[21]$} \\
\hline Persea americana & Seed & Carboxylic acid acid alkanes & Spherical; 42-90 nm & $\begin{array}{l}\text { Antibacterial, antifungal and } \\
\text { antioxidant activities }\end{array}$ & [125] \\
\hline Quisqualis indica & Floral parts & Alcohols and phenols & Spherical; $39.3 \pm 5.45 \mathrm{~nm}$ & $\begin{array}{l}\text { Suppression of B16F10 melanoma } \\
\text { cell proliferation and inhibition of } \\
\text { tumor growth }\end{array}$ & [95] \\
\hline Ziziphus spina-christi & Fruit & Alcohols and phenols & $\begin{array}{l}\text { Cubic type; FESEM:8-15 nm, } \\
\text { XRD:8-15 nm }\end{array}$ & $\begin{array}{l}\text { Nanoadsorbent and antibacterial } \\
\text { activity }\end{array}$ & {$[96]$} \\
\hline
\end{tabular}


frequency. It is difficult to distinguish between $\mathrm{Cu}-\mathrm{O}$ of cupric oxide and those of cuprous oxide as the NPs may be a mixture of both the $\mathrm{CuO}$ and $\mathrm{Cu}_{2} \mathrm{O}$. Since the gum used in this work is a naturally occurring bio-polymer it contains sugars and amino acids which act as reducing as well as capping agent for CuO-NPs. Also they remain adhered to the surface of the gum matrix through electrostatic force. Abboud et al. [56] have reported the fabrication of CuO-NPs from Bifurcaria bifurcate (brown alga) purely in aqueous medium. Formation of NPs was ascertained from a change in colour from dark blue $\rightarrow$ colourless $\rightarrow$ deep red $\rightarrow$ black. It was a slow process but on heating at $100{ }^{\circ} \mathrm{C}$ the reduction of $\mathrm{Cu}^{2+}$ to $\mathrm{CuO}$ NPs was facilitated [57]. UV-Vis spectrum of CuO-NPs exhibited peaks at 260 and $650 \mathrm{~nm}$. The former was assigned to cuprous oxide NPs and the latter has been attributed to cupric oxide NPs [58, 59]. Terpenoids present in the algal extract are responsible for the reduction ofCu ${ }^{2+}$ to $\mathrm{CuO}-\mathrm{NPs}$. However, the peak observed at $260 \mathrm{~nm}$ in the UV-region cannot be assigned to the presence of cuprous oxide NPs because metal oxides (owing to their colour) can absorb only in the visible region of the spectrum. The colour of the colloidal mixture is neither purely black nor reddish. It is reddish black owing to the presence of both the cuprous and cupric oxide NPs which is also supported by uneven distribution and two crystalline phases corresponding to mono-clinic cupric oxide $(\mathrm{CuO})$ and cubic cuprous oxide $\mathrm{Cu}_{2} \mathrm{O}$ NPs $[45,59,60]$. There were two types of NPs identified from TEM images. Spherical ones were in abundance along with some elongated $\mathrm{CuO}$-NPs ranging between 5 and $45 \mathrm{~nm}$ diameters. Diterpenoids are the major components in alga which work as reductant and stabilizer for CuO-NPs [61].

Fabrication of CuO-NPs from leaf extract (Aloe vera) by Vijay Kumar et al. [62] were shown to be monoclinic with an average particle size of $20 \mathrm{~nm}$. Vishveshvar et al. [63] have shown $\mathrm{CuO}-\mathrm{NPs}$ (obtained from Ixoro coccinea leaf extract) of an average size of $300 \mathrm{~nm}$ because of the formation of NP clusters. CuO-NPs obtained from Ruellia tuberosa aqueous extract were characterized by UV-Vis, FTIR, TEM, FE-SEM, EDAX and DLS [64]. In this experiment, the aqueous copper sulphate solution was added to the leaf extract showing a pale yellow to brownish black colour which had indicated the formation of CuO-NPs Fig. 3a). The absorption peak at 327 $\mathrm{nm}$ was confirmed by SPR (Fig. $3 \mathrm{~b}$ ) and also the formation of $\mathrm{CuO}$ nanorods of $\sim 83.23 \mathrm{~nm}$. Further, the FTIR studies have shown the characteristic peaks at $452 \mathrm{~cm}^{-1}$, $612 \mathrm{~cm}^{-1}, 794 \mathrm{~cm}^{-1}, 893 \mathrm{~cm}^{-1}, 1120 \mathrm{~cm}^{-1}, 1652 \mathrm{~cm}^{-1}$ and $3184 \mathrm{~cm}^{-1}$ in $500-4000 \mathrm{~cm}^{-1}$ range (Fig. 3c). Bands at $3184 \mathrm{~cm}^{-1}$ exhibited $\mathrm{O}-\mathrm{H}$ stretch due to carboxylic acids, those at $1652 \mathrm{~cm}^{-1}$ established $-\mathrm{C}=\mathrm{C}$ - bending due to alkenes. Strong bands at $1120 \mathrm{~cm}^{-1}$ exhibited the presence of $\mathrm{C}-\mathrm{O}$ stretch due to alcohols and esters. The peak at $893.62 \mathrm{~cm}^{-1}$ has been assigned to $\mathrm{C}-\mathrm{H}$ bending due to aromatic groups. Strong peaks at 452 $\mathrm{cm}^{-1}, 612 \mathrm{~cm}^{-1}$ and $794 \mathrm{~cm}^{-1}$ revealed the presence of $\mathrm{Cu}-\mathrm{O}$ vibrations in the fabricated CuO-NPs. Vasantharaj et al. [64] have suggested that the FTIR investigation had confirmed the availability of carboxylic acids, alkenes, esters, alcohols and aromatic compounds in the biofabricated $\mathrm{CuO}-\mathrm{NPs}$. Fabrication of $\mathrm{CuO}-\mathrm{NPs}$ from leaf extract of Psidium guajava has been reported by Singh et al. [65]. In this investigation, CuO-NPs of different shapes and size ranging from nanorods to nano spheres were found.

$\mathrm{CuO}-\mathrm{NPs}$ from Eichhornia crassipes weed has been successfully synthesized in aqueous medium under laboratory conditions [66]. The colloidal solution containing $\mathrm{CuO}-\mathrm{NPs}$ and weed extract showed absorption at $310 \mathrm{~nm}$ in UV-Vis spectrum. SEM and TEM images showed spherical shaped $\mathrm{CuO}-\mathrm{NPs}$ of approximately 28 $\mathrm{nm}$. It is interesting to note that $\mathrm{CuO}-\mathrm{NPs}$ were free from impurity which is confirmed from EDX pattern which showed peaks only for copper and oxygen.

Ghidan et al. [67] have also investigated the biosynthesis of CuO-NPs from aqueous peel extract of Punica granatum at room temperature. It has been observed that peel extract contains amines amino acids and phenols which reduce copper ions to $\mathrm{CuO}-\mathrm{NPs}$. Crystalline and spherical NPs of nearly $40 \mathrm{~nm}$ size were found to be agglomerated. SEM images showed particles of 10-100 $\mathrm{nm}$. Toxicity of $\mathrm{CuO}-\mathrm{NPs}$ was investigated against the mortality of green peach Aphids at different concentrations. Maximum mortality was observed at $8000 \mu \mathrm{g} / \mathrm{ml}$ which is quite significant.

Sivaraj et al. [68] have synthesized CuO-NPs from Tabernaemontana divaricate leaf extract in water. They were obtained in good yield as brownish black powder and identified from a peak between 220 and $225 \mathrm{~nm}$ in UV-Vis spectrum. Presence of phenol, amine and proteins has been suggested on the basis of IR spectral peaks. Spherical CuO-NPs of $48 \pm 4 \mathrm{~nm}$ appear to be in pure state as the EDX showed sharp signals only for copper and oxygen [69]. These NPs inhibit the growth

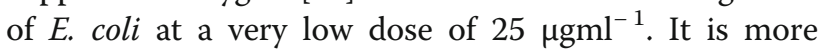
than twice as effective as tetracycline.

CuO-NPs from dried aqueous fruit extract (Tribulus terrestris) has been shown to contain carbonyl and hydroxyl groups in the fruit extract [70]. Although many other compounds are suspected to be present in the extract the IR spectrum exhibited the presence of a single component. CuO-NPs of 5-22 nm size were dispersed nicely and biological molecules in the extract appear to be deposited on them.

Aqueous leaf extract of Pterospermum acerifolium has been used to synthesize CuO-NPs from hydrated copper 

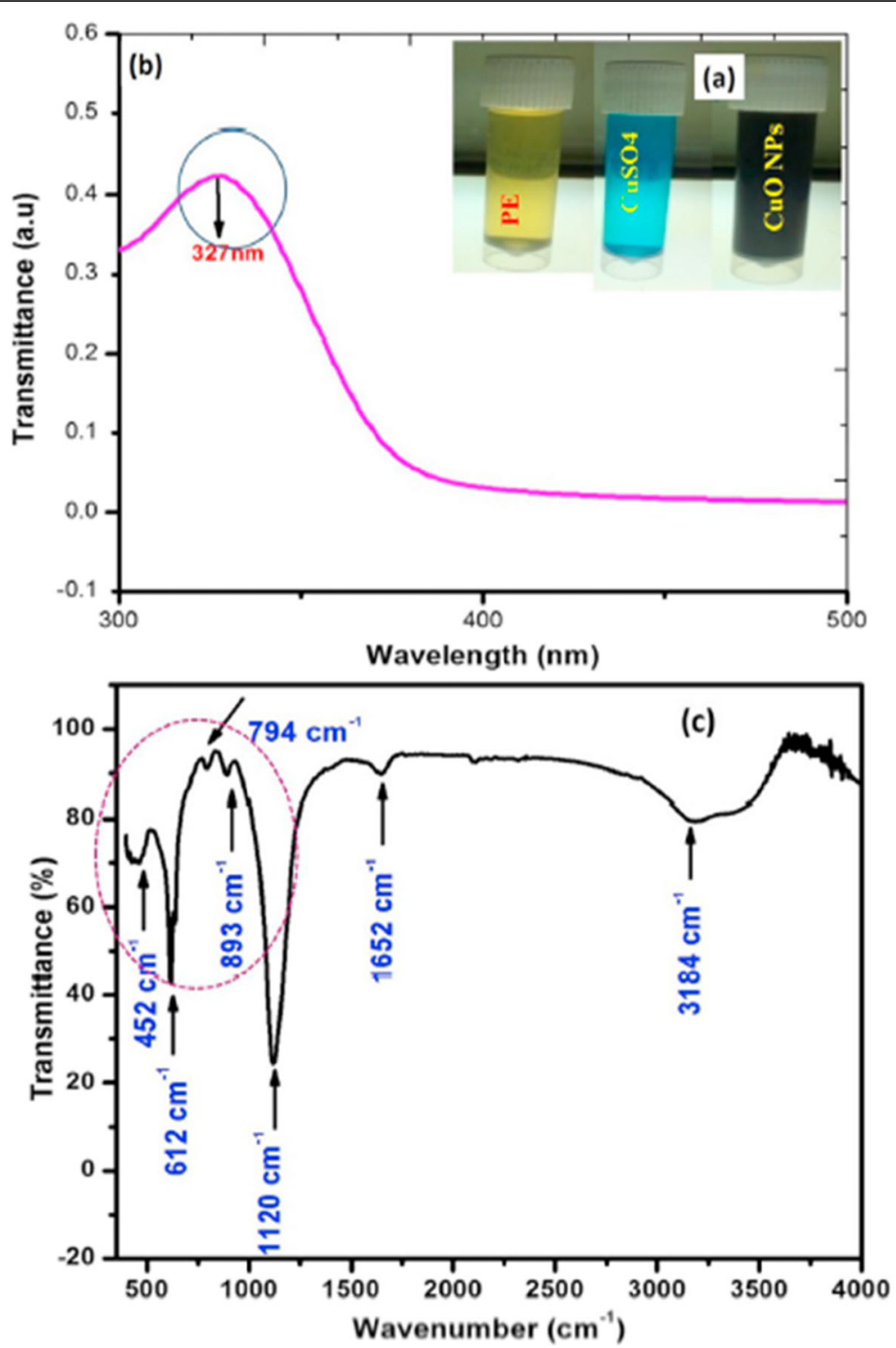

Fig. 3 a Colouration of bio-fabricated CUO-NPS, b surface plasmon resonance UV-vis spectrum, c FTIR spectrum of CuO-NPS as fabricated from Ruellia tuberosa aqueous extract [64]

nitrate [71]. NPs were oval shaped and pure as evidenced from EDX. They were more stable than the engineered NPs. However, hydrodynamic diameter of plant mediated CuO-NPs increased from $212 \pm 47$ to $634 \pm 40$ $\mathrm{nm}$, whereas the particle size of engineered NPs increased up to $1037 \pm 171 \mathrm{~nm}$ after $72 \mathrm{~h}$. This property of increasing the hydrodynamic diameter may be used to control the size of CuO-NPs in aqueous medium. Perhaps the green synthesized NPs are capped by the phytochemicals present in the leaf extract and are therefore less aggregated. It has been noted that the rate of release of copper ions from engineered $\mathrm{CuO}-\mathrm{NP}$ is much faster than plant synthesized NPs for identical concentration. It has been ascribed to stability and capping of plant synthesized CuO-NPs. It can be more effective and lasting if used in crop protection against pest and microbes as it is antibacterial in nature. Copper ion release is dependent on time, concentration and temperature to some extent [72, 73].

$\mathrm{CuO}-\mathrm{NPs}$ and dissolved copper generally accumulate over the organisms exposed to them. Effect of NPs and free copper ions on Elodea nuttallii has been studied by Regier et al. [74]. CuO-NPs with large hydrodynamic size $(1059 \pm 88 \mathrm{~nm})$ very quickly agglomerate and did not change even when irradiated with UV light. Uptake of $\mathrm{CuO}-\mathrm{NPs}$ in suspension by $E$. nuttallii is less than the dissolved copper [75]. However, it is contradictory because large quantity of accumulated copper has been 
found in Landoltia punctata when exposed to CuO-NPs than when they were exposed to similar concentration of dissolved copper [76]. It has been argued that copper is solubilized from $\mathrm{CuO}-\mathrm{NPs}$ due to acid exuded from growing shoots. However, copper ions would be available only if reduction of CuO-NPs occurs followed by its oxidation.

$$
\begin{aligned}
& \mathrm{CuO}+\mathrm{H}_{2} \text { Redn } \rightarrow \mathrm{Cu}+\mathrm{H}_{2} \mathrm{O} \\
& \mathrm{Cu} \mathrm{Oxdn} \rightarrow \mathrm{Cu}^{2+}+2 \mathrm{e}
\end{aligned}
$$

It is obvious that more copper ions will be available from copper salts because it is highly ionized in water and can be transported to different parts of plants through osmosis. CuO-NPs get accumulated due to large size.

$$
\mathrm{CuSO}_{4} \leftrightharpoons \mathrm{Cu}^{2+}+2 \mathrm{e}^{-}
$$

$\mathrm{CuO}-\mathrm{NPs}$ from Gloriosa superb leaf extract in water have been synthesized [77]. Spherical CuO-NPs of 8-17 $\mathrm{nm}$ were obtained in pure state as the XRD pattern shows single phase monoclinic structure although SEM images show particles of smaller size $(5-10 \mathrm{~nm})$.

Formation of CuO-NPs from Carica papaya leaf extract has been reported [78]. A sharp peak in the FTIR spectrum of colloidal cupric oxide NPs at $473 \mathrm{~cm}^{-1}$ has been taken as an evidence for its formation. Presence of cuprous oxide NPs has been eliminated due to absence of any characteristic peak around $605-660 \mathrm{~cm}^{-1}$. Rod shaped $\mathrm{CuO}-\mathrm{NPs}$ of $140 \mathrm{~nm}$ are crystalline and have FCC structure [79]. Larger particles $(614 \mathrm{~nm})$ are not monodispersed perhaps due to capping by the phytochemicals in the papaya leaf extract.

Leaf extract of Calotropis gigantea has also been used for the fabrication of CuO-NPs. Steriods and polyphenols in the extract reduce $\mathrm{Cu}^{2+}$ ions to CuO-NPs and also act as stabilizer for them. It has been stated [26] that oxygen of ester and phenols form metal chelate with copper ion. On heating the chelate complex, $\mathrm{CuO}-\mathrm{NPs}$ are obtained. It is surprising that the authors have said that $\mathrm{CuO}-\mathrm{NPs}$ are formed by the phytochemicals and pure NPs are obtained after heating at $400^{\circ} \mathrm{C}$. A metal complex can be formed by a metal ion only. Free metal in atomic state cannot form a complex. A chelate with phenol cannot be formed as it is a monodentate ligand and cannot form a ring. By heating copper nitrate at $400{ }^{\circ} \mathrm{C}, \mathrm{CuO}-\mathrm{NPs}$ cannot be obtained because oxidation of copper to $\mathrm{CuO}$ can occur only at $900{ }^{\circ} \mathrm{C}$. CuO-NPs were already formed by the leaf extract, and there were no complex whatsoever. Such hypothesis is baseless. Heating at $400{ }^{\circ} \mathrm{C}$ will cause burning of any organic matter left in excess and shall leave soot or carbon as impurity. Spherical CuO-NPs of $20-30 \mathrm{~nm}$ were formed as the
EDX showed peaks only for copper and oxygen separately. The NPs were not well scattered.

Natural phytochemicals are frequently used for the fabrication of metal and or metal oxide NPs. A facile synthesis of CuO-NPs from Gundelia tournefortii aqueous extract of has been reported [80]. It has been shown that $\mathrm{Cu}^{2+}$ to $\mathrm{CuO}-\mathrm{NPs}$ conversion occurs after heating the mixture of plant extract and $\mathrm{CuCl}_{2}$ at $60^{\circ} \mathrm{C}$ for $2 \mathrm{~h}$. IR spectra of extract and NPs exhibited the presence of phenolic compounds absorbed on the surface of $\mathrm{CuO}$ NPs $[81,82]$. NPs are highly crystalline [80] and spherical. Authors have concluded from EDX pattern that the presence of oxygen refers to the oxidation of $\mathrm{Cu}-\mathrm{NPs}$ when exposed to air. It is not true because the $\mathrm{Cu}$ and oxygen peaks are due to $\mathrm{CuO}-\mathrm{NPs}$.

$\mathrm{CuO}-\mathrm{NPs}$ fabricated from the aqueous flower extract of Anthemis nobilis had FCC, crystalline structure [83]. These NPs were found to be useful for the synthesis of propargylamines in moderate yield. Vegetable peels have also been used for the synthesis of CuO-NPs [84]. Cauliflower (Brassica oleracea), potato (Solanum tuberosum) and pea (Pisum sativum) peel extracts yield $\mathrm{CuO}-\mathrm{NPs}$ from $\mathrm{CuCl}_{2} .2 \mathrm{H}_{2} \mathrm{O}$. This reaction was very slow as it took $24 \mathrm{~h}$ at $60^{\circ} \mathrm{C}$ to yield NPs. All NPs obtained from the above sources were monoclinic ranging from 22.2 to $31.60 \mathrm{~nm}$. Since IR spectra did not show any peak at $610 \mathrm{~cm}^{-1}$ the presence of $\mathrm{Cu}_{2} \mathrm{O}$ was ruled out [85]. As the $\mathrm{Cu}_{2} \mathrm{O}$ is deep red it could have been easily noticed. Distinction between $\mathrm{Cu}_{2} \mathrm{O}$ and $\mathrm{CuO}$ can hardly be made on the basis of $\mathrm{Cu}-\mathrm{O}$ stretching frequencies as they are very closely spaced. Morphology of $\mathrm{CuO}$-NPs prepared from different vegetable wastes vary in size. Their catalytic activity is also different from each other due to their shape, size and concentration.

Mixed metal nanomaterials have also gained popularity due to their multidisciplinary application. Biofabrication of $\mathrm{Pd} / \mathrm{CuO}-\mathrm{NPs}$ from Theobroma cacao seed extract and their application as catalyst has been reported [86]. The $\mathrm{Pd} / \mathrm{CuO}-\mathrm{NPs}$ were highly stable because no change was observed even when it was left for 30 days. Antioxidants like epicatechin, catechin and their derivatives in cocoa seed extract act as strong reducing as well as capping agent. Pd has face centered cubic structure mixed with $\mathrm{CuO}-\mathrm{NPs}$ of about $40 \mathrm{~nm}$. Agglomeration is prevented due to capping of $\mathrm{Pd} / \mathrm{CuO}$ NPs. Presence of oxygen in EDS spectrum has been ascribed to oxidation of $\mathrm{Cu}$ NPs to CuO-NPs. When $\mathrm{Pd} /$ $\mathrm{CuO}$ does not contain free copper ions what is the need of oxygen for oxidation of CuO-NPs. However, oxidation of metallic copper in presence of water can take several hours nevertheless it would give $\mathrm{CuSO}_{4}$ with a characteristic blue colour. However, authors assumption needs verification. The mechanism proposed for the formation of metal NPs and their nucleation is not convincing. All 
the phenolic $-\mathrm{OH}$ groups cannot be oxidized even in multiple steps as the drainage of electron from it will make the ring unstable. If such nucleation occurs a metal cluster would be formed.

Seeds of many leguminous plants also contain fairly reasonable amount of proteins, phenols, flavonoids, alkaloids and amino acids [87-89] and hence they are used as reducing agent to synthesize metal NPs. Crystalline monoclinic $\mathrm{CuO}-\mathrm{NPs}$ of $26.6 \mathrm{~nm}$ have been synthesized from black been extract and their anti-cancer activity against HeLa cells has been reported [90]. They were effective in a very low concentration range $\left(0.5-1 \mathrm{mg} \mathrm{ml}^{-1}\right)$ and short duration of time (12-48 h). It has been ascribed to intracellular ROS generation in a dose dependent manner.

The mechanism suggested for the formation of $\mathrm{CuO}$ NPs is beyond imagination and conceptually non convincing. Authors have argued that the precursor $\mathrm{CuSO}_{4}$ reacts with hydroxyl anion $\mathrm{OH}_{-}$, generated by the ionization of water molecules and eventually reduced by phytochemicals present in the seed extract. It must be clarified at this stage that:

(a) It is universally known that water is not ionized until acidified water is electrolysed and (b) $\mathrm{Cu}(\mathrm{OH})_{2}$ can be formed only if $\mathrm{NaOH}$ or requisite amount of $\mathrm{NH}_{4} \mathrm{OH}$ is added to a copper salt as shown below.

$$
\begin{aligned}
& \mathrm{CuSO}_{4}+2 \mathrm{NaOH} \rightarrow \mathrm{Cu}(\mathrm{OH})_{2}+\mathrm{Na}_{2} \mathrm{SO}_{4} \\
& \mathrm{CuSO}_{4}+2 \mathrm{NH} 4 \mathrm{OH} \rightarrow \mathrm{Cu}(\mathrm{OH})_{2}+\left(\mathrm{NH}_{4}\right)_{2} \mathrm{SO}_{4}
\end{aligned}
$$

However, $\mathrm{CuSO}_{4}$ remains ionized in aqueous medium or it may form hexaaquo copper complex, $\left[\mathrm{Cu}\left(\mathrm{H}_{2} \mathrm{O}\right)_{6}\right]$.

$$
\mathrm{CuSO}_{4} \leftrightharpoons \mathrm{Cu}^{2+}+\mathrm{SO}_{4}{ }^{2-}
$$

Free $\mathrm{Cu}^{2+}$ ion is then reduced by protein or polyphenol available in the black bean extract. Phenol is oxidized to phenolate ion which provides electron to $\mathrm{Cu}^{2+}$ ions to from CuO-NPs.

Bawadi [91] and Bobe et al. [92] have reported that black bean extract inhibits the proliferation of breast, colon liver and prostate cancer cell. Also, it does not interfere with the functioning of healthy cells [93, 94]. It is still not understood as to why some peel/plant extract yield $\mathrm{Cu}-\mathrm{NPs}$ and some of them produce $\mathrm{CuO}-\mathrm{NPs}$ from the same precursor. As such $\mathrm{CuSO} 4$ will produce $\mathrm{Cu}^{2}+$ ions in aqueous medium and reduced to $\mathrm{Cu}$-NP by phytochemicals. For $\mathrm{CuO}-\mathrm{NPs}, \mathrm{Cu}^{2}+$ is to be reduced to $\mathrm{Cu}-\mathrm{NPs}$ and subsequently oxidized to $\mathrm{CuO}-\mathrm{NPs}$. However, its whole chemistry is yet to be investigated. Further details of various plant species and their parts used in $\mathrm{Cu}$-NPs synthesis and other associated activities are presented in Table 2.

\section{Application of Cu-NPs/CuO-NPs}

Application of $\mathrm{Cu}-\mathrm{NPs} / \mathrm{CuO}-\mathrm{NPs}$ has been consolidated in Tables 1, 2 and Fig. 4.

\section{Antibacterial activity}

Antibacterial activity of foam coated and uncoated $\mathrm{Cu}$ NPswas screened. Biosynthesized Cu-NPs from Magnolia kobus aqueous leaf extract exhibited greater activity against Escherichia coli than those shown by chemically fabricated NPs [29]. Antibacterial activity of $\mathrm{Cu}-\mathrm{NPs}$ synthesized from Citron juice (Citrus medica) was examined [49]. In vitro antimicrobial activity screened against Escherichia coli, Klebsiella pneumoniae, Pseudomonas aeruginosa, Propionibacterium acnes and Salmonella typhi showed that $\mathrm{Cu}$-NPs were significantly effective against them. However, among the examined plant pathogenic fungi, Fusarium culmorum was observed to be most sensitive followed by $F$. oxysporum and F. gra-

\begin{tabular}{|c|c|c|c|c|c|}
\hline Plant & $\begin{array}{l}\text { Part of plant } \\
\text { used }\end{array}$ & Active compounds & Shape and size & Various applications & Key references \\
\hline Aloe vera & Leaf & - & Octahedral; 24-61 nm & Photocatalytic activity & [126] \\
\hline Ferulago angulate & Aerial part & - & $\begin{array}{l}\text { Shell like sheet structure; } \\
44 \mathrm{~nm}\end{array}$ & Photocatalytic activity & {$[127]$} \\
\hline Galeopsidis herba & Plant extract & Flavonoids and phenolic acids & Spherical; $10 \mathrm{~nm}$ & $\begin{array}{l}\text { Antioxidant and catalytic } \\
\text { activity }\end{array}$ & [128] \\
\hline Ixoro coccinea & Leaf & $\begin{array}{l}\text { Carboxylic acids, alkenes, esters, } \\
\text { alcohols and aromatic compounds }\end{array}$ & $\begin{array}{l}\text { Spherical; SEM: } 300 \mathrm{~nm} \text {; T } \\
\text { EM: } 80-110 \mathrm{~nm}\end{array}$ & - & [63] \\
\hline Malus domestica & Leaf & $\begin{array}{l}\text { Carbonyl, methyl, saturated } \\
\text { aliphatic and alkane/alkyl groups }\end{array}$ & $\begin{array}{l}\text { Spherical and crystalline; } \\
18-20 \mathrm{~nm}\end{array}$ & $\begin{array}{l}\text { DNA cleavage, antibacterial } \\
\text { and antioxidant activities }\end{array}$ & [129] \\
\hline Psidium guajava & Leaf & - & Spherical; 2-6 nm & Photocatalytic activity & {$[65]$} \\
\hline Stachys lavandulifolia & Leaf & - & Less than $80 \mathrm{~nm}$ & Antifungal activity & [130] \\
\hline Terminalia belerica & Fruits & - & Spherical; 9-14 nm & Antibacterial activity & [131] \\
\hline Ruellia tuberosa & Leaf & $\begin{array}{l}\text { Carboxylic acids, alkenes, esters, } \\
\text { alcohols and aromatic compounds }\end{array}$ & Nanorods; 83.23 nm & $\begin{array}{l}\text { Antibacterial and } \\
\text { photocatalytic activities }\end{array}$ & [64] \\
\hline
\end{tabular}
minearum. $\mathrm{Cu}$ NPs synthesized from Punica granatum

Table 2 Recent studies (during 2018-19) on plant-mediated synthesis of CuO-NPs, their morphology and various applications 


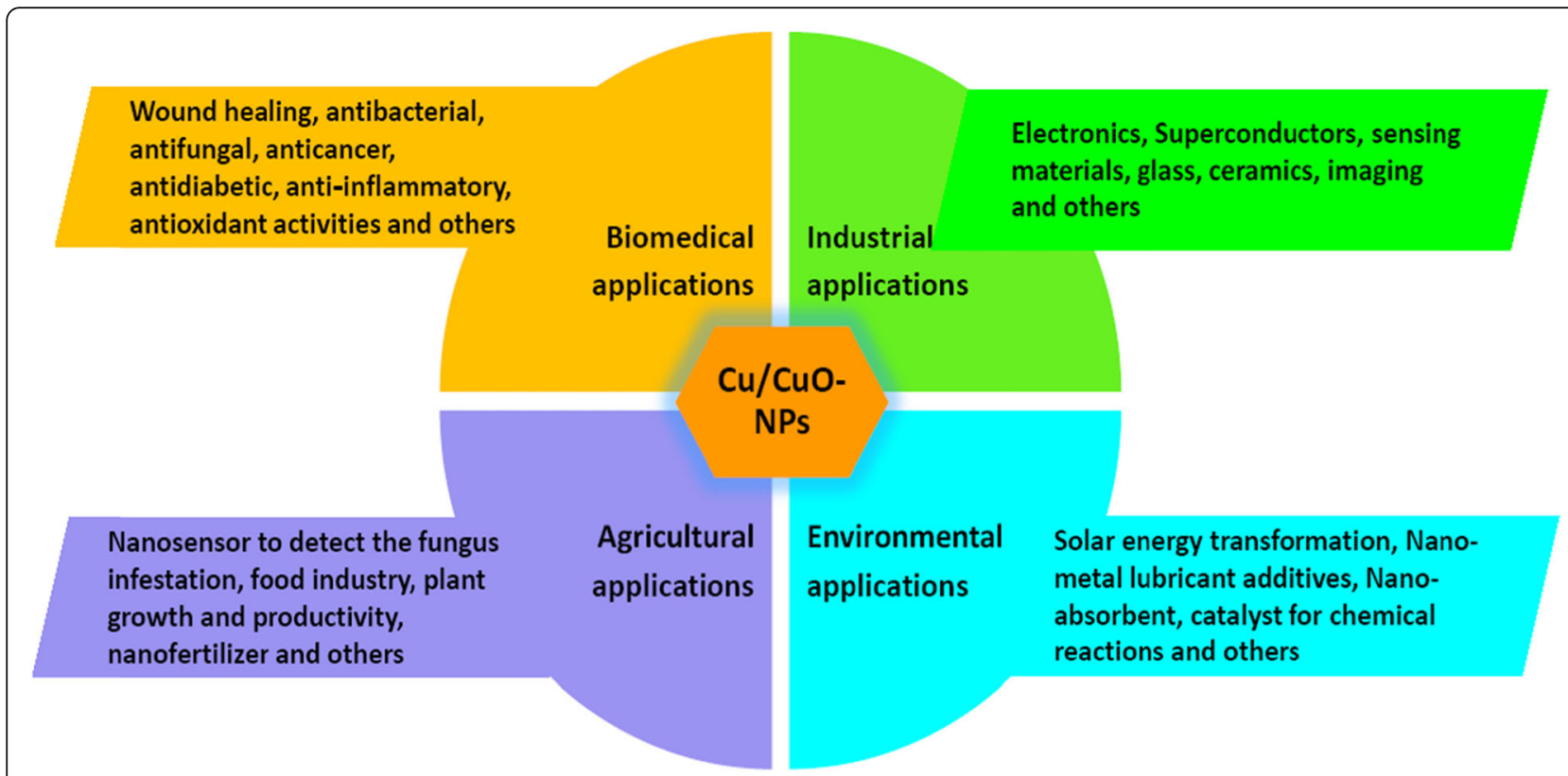

Fig. 4 Application of Cu-NPs/CuO-NPs in biomedical, industrial, agricultural and environmental sectors

peel extract have been found to be highly bactericidal against Micrococcus luteus, Pseudomonas aeruginosa, Salmonella enterica and Enterobactor aerogenes [51]. Their antibacterial efficacy was higher than that exhibited by standard antibiotic, streptomycin [97-99].. Biosynthesized $\mathrm{Cu}-\mathrm{NPs}$ from Millettiapinnata flower extract of was examined against some pathogenic bacteria [21]. These particles were found to be more effective against Staphylococcus aureus and Bacillus subtilis (gram-positive) than Pseudomonas aeruginosa and E. coli (gram-negative).

$\mathrm{CuO}-\mathrm{NPs}$ obtained from gum karaya showed very high antibacterial activity against E. coli and S. aureus [96]. Efficacy was found to be dependent on the size of NPs [100], the thickness of bacterial cell wall and incubation time. Smaller particles were more toxic than larger ones even if they do not penetrate the bacterial cell wall. Fabrication of CuO-NPs from Bifurcaria bifurcate have also been found to be significantly antibacterial against $E n-$ terobacter aerogenes and Staphylococcus aureus [56]. Bactericidal property has been attributed to the release of copper ions and their interaction with microbial cells. $\mathrm{CuO}-\mathrm{NPs}$ obtained from an aquatic noxious weed, Eichhorni acrassipes have been found to act as growth inhibitor of Fusarium culmorum and Aspergillus niger [66].CuO-NPs obtained from the aqueous dried fruit extract of Tribulus terrestris were examined for their in vitro cytotoxicity and antibacterial activity [70]. CuONPs also inhibit the growth of bacterial strains but they were found to be most effective against Escherichia coli [68]. SEM images of bacterial cells exposed to CuO-NP showed complete rupture of cell wall in $60 \mathrm{~min}$ which suggested that efficiency is time dependent. However, when bacteria were exposed to different concentrations of $2.5-100 \mu \mathrm{g} / \mathrm{ml}$ for about $1 \mathrm{~h}$ maximum decrease was found for lowest concentration. CuO-NPs obtained from Gloriosa superba leaf extract and examined for their antibacterial activity against Klebsiella aerogenes, Pseudomonas desmolyticum, E. coli and Staphylococcus aureus has been investigated [74]. CuO-NPs indicated significant activity against all bacterial strains but there is no conclusive study to propose a mechanism of action.

\section{Catalytic activity}

Synthesis of $\mathrm{Cu} / \mathrm{RGO}-\mathrm{Fe}_{3} \mathrm{O}_{4} \quad(\mathrm{Cu} /$ Reduced graphene oxide- $\mathrm{Fe}_{3} \mathrm{O}_{4}$ ) nanocomposite from barberry fruit juice (Berberis vulgaris) and its application as a heterogeneous catalyst for the ortho arylation of phenols in presence of aryl halide has been reported [101]. It is interesting to note that nano composite was easily recovered and used several times without loss of catalytic activity. Since, barberry fruit juice contains mainly vitamin $\mathrm{C}$ and polyphenols, they act as reducing and capping agent for $\mathrm{Cu}$-NPs. Although, CuO-NPs have been used in the hydration of phenylcyanamide to urea the yield was very small, it improved by increasing the temperature of reaction mixture. Reduction of 4-nitrophenol to 4-aminophenol by $\mathrm{NaBH}_{4}$ in presence of CuO-NPs has also been done. It takes only 70s for complete reduction but in absence of CuO-NPs the same reaction is not initiated even after 3 h. Fabrication and catalytic activity of $\mathrm{Pd} / \mathrm{CuO}-\mathrm{NPs}$ using Theobroma cacao was investigated through Heck coupling reaction and through reduction of nitrophenol 
to aminophenol [86]. The catalyst was reused up to $6 \mathrm{cy}-$ cles. Mechanistic pathway is yet to be established. $\mathrm{Cu}$ NPs from aqueous leaf extract of Euphorbia esula has also been used for catalytic reduction of 4-nitrophenol and ligand free Ullmann-coupling reaction [50].

The CuO-NPs fabricated from the leaf extract of Psidium guajava has exhibited a remarkable degradation efficiency against the industrial dyes. It degraded Nile blue by $93 \%$, and reactive yellow 160 by $81 \%$ in just 120 min with apparent rate constants of 0.023 and $0.014 \mathrm{~min}^{-1}$, respectively [65].CuO-NPs obtained from Carica papaya leaf extract has been exploited in the photocatalytic degradation of Coomassive brilliant blue dye in sunlight [78].

\section{Plant growth response}

Plants are very susceptible to minor changes in the environment (abiotic stress) and supply of any trace element/NPs either as a nutrient or as a foreign matter [28, 102-108]. Cu-NPs enhanced the root and shoot growth of mung bean [109], but reduced shoot growth in wheat [110]. Yasmeen et al. [111] synthesized $\mathrm{Cu}$ and Fe-NPs and demonstrated their role on the growth as well as yield of wheat varieties. The metal NPs synthesized from onion extract of $15-30 \mathrm{~nm}$ diameters had irregular shape. Wheat varieties were treated with $20,25,30,35$ and $40 \mathrm{ppm} \mathrm{Cu}-\mathrm{NPs}$ at different stages of growth until production of seeds. Spike length was invariably increased or remained unchanged when treated with 25 ppm Cu-NPs but significantly increased the number of grains. However, higher $\mathrm{Cu}$ concentration reduced the number of grains/spike and overall 1000 grain weight. Copper and iron NPs together at 25 ppm concentration have better effect on production and yield of wheat than copper or iron alone. $\mathrm{Cu}$-NPs increased the grain yield and stress tolerance in wheat plant through starch degradation. Sugar content and SOD activity was enhanced in seeds treated with copper and iron NPs. Quantity of copper was increased while iron remained unchanged in seeds treated with $\mathrm{Cu}$ and Fe NPs [111].

ACF coated with copper and stabilized with sodium dodecyl sulphate have been used as carrier for copper transport [53]. It was calcined at 350 to $\mathrm{CuO}$-ACF and finally reduced in a current of hydrogen to generate $\mathrm{Cu}$ ACF carbon nanofibers. They were then grown on $\mathrm{Cu}-$ ACF to produce $\mathrm{Cu}-\mathrm{CNF} / \mathrm{ACF}$ [112]. The Cicer arietinum plant treated with $\mathrm{Cu}-\mathrm{CNF}$ grew well in comparison to control plants.

Impact of engineered $\mathrm{CuO}-\mathrm{NPs}$ on growth and development of Arabidopsis thaliana at molecular level has been explored [113]. Their seedlings were treated with different doses of CuO-NPs for 3 weeks. Plant biomass, total chlorophyll content and root elongation invariably decreased while an increase in anthocyanin, lipid peroxidation and proline were observed. Lignin was also found to be deposited in root. CuO-NPs treated seedlings also showed an increase in superoxide and hydrogen peroxide in leaves and roots which is directly proportional to its concentration. As a consequence of oxidative stress, the main root growth was inhibited but lateral root formation was initiated. This is mainly due to metabolic imbalance and as a response to resistance caused by CuO-NPs [114]. However, the plant system in response to such stress produces antioxidants to prevent the damage by ROS $[104,105,115]$ which subsequently causes some changes in metabolic functions. Very recently, Chung et al. [116] have examined the effect of CuO-NPs on Brassica rapa seedlings. CuO-NPs treated seedlings have shown reduced root and shoot length, chlorophyll, carotenoid and sugar content, while proline and anthocyanins were increased. Additionally, production of malondialdehyde and hydrogen peroxide were increased in $\mathrm{CuO}-\mathrm{NPs}$ treated seedlings which has been associated with DNA damage.

\section{Miscellaneous response}

Recently, the biosynthesized $\mathrm{Cu}-\mathrm{NPs}$ from flower extract of Millettia pinnata have also been shown to exhibit anti-diabetic and anti-inflammatory activities [21]. Human mesenchymal stem cells exposed to CuO-NPs at a concentration of $25 \mathrm{\mu g} \mathrm{ml}^{-1}$ reduced their viability. $\mathrm{CuO}-\mathrm{NPs}$ at a dose of or below $10 \mu \mathrm{g} / \mathrm{ml}$ were non toxic to normal cells and therefore, a safe concentration may be used to prevent the interaction of $\mathrm{CuO}$-NPs with normal mesenchymal cells. It has been suggested that $\mathrm{CuO}$ NPs release $\mathrm{Cu}$ ions which are antibacterial and anticancerous $[117,118]$. It also means that reduction of $\mathrm{Cu}-$ NPs to copper ions occur which are toxic to normal bacterial cells and cancer cells in mammals. Toxicity of CuO-NPs obtained from aqueous leaf extract of Pterospermum acerifolium was determined against Daphnia magna at several concentrations [71]. The engineered NPs were several times more toxic to Daphnia than green synthesized NPs $[119,120]$. Release of copper ions from CuO-NPs is the main cause of toxicity to Daphnia. Dissolved copper ions from CuO-NPs get accumulated around Daphnia which cause toxicity.

\section{Conclusion}

Plenty of nano particles are synthesized every year but only some of them are put to beneficial use. Green synthesized NPs of desired shape, size and stability can enhance their overall qualities for future applications. It appears that all plant species contain some type of phytochemicals which reduce the metal salts and metal oxides into their NPs. $\mathrm{Cu}$ and $\mathrm{CuO}-\mathrm{NPshave}$ shown great promise as biocide and mild antibacterial agent. Even though, biofabrication of metal NPs from plants and microbes do not leave toxic residues in environment, their 
safe disposal is necessary. Further, it is also essential to utilize the fabricated $\mathrm{Cu}$ and $\mathrm{CuO}-\mathrm{NPs}$ as biomedicine, environmental remediation and agricultural practices. Attention must be focused on their biocompatibility.

\section{Abbreviations}

NPs: Nanoparticles; Cu-NPs: Copper nanoparticles; CuO-NPs: Cupric-oxide nanoparticles; UV-Vis: Ultraviolet-visible spectroscopy; SEM: Scanning electron microscopy; TEM: Transmission electron microscopy; XRD: X-ray diffraction; FTIR: Fourier transform infrared spectroscopy; SAED: Selected area (electron) diffraction; EDAX: Energy-dispersive x-ray spectroscopy; ACF: Activated carbon microfibers.

\section{Acknowledgements}

Authors are thankful to publishers for permission to adopt figures in this review.

\section{Authors' contributions}

$\mathrm{AH}$ gathered the research data. KSS and $\mathrm{AH}$ analyzed these data and wrote this review paper. Both authors read and approved the final manuscript.

\section{Funding}

Not applicable.

\section{Availability of data and materials}

Not applicable.

\section{Ethics approval and consent to participate}

Not applicable.

\section{Consent for publication}

Not applicable.

\section{Competing interests}

The authors declare that they have no competing interests.

\section{Author details}

'Department of Chemistry, Aligarh Muslim University, Aligarh, Uttar Pradesh 202002, India. ${ }^{2}$ Wolaita Sodo University, P.O. Box: 138, Wolaita, Ethiopia.

Received: 11 March 2020 Accepted: 5 May 2020

Published online: 03 June 2020

\section{References}

1. Husen A, Siddiqi KS. Phytosynthesis of nanoparticles: concept, controversy and application. Nano Res Lett. 2014;9:229.

2. Siddiqi KS, Husen A, Rao RAK. A review on biosynthesis of silver nanoparticles and their biocidal properties. J Nanobiotechnol. 2018;16:14

3. Husen A. Introduction and techniques in nanomaterials formulation: An overview. In: Husen A, Jawaid M, editors. Nanomaterials for Agriculture and Forestry Applications. Cambridge: Elsevier Inc; 2020. p. 1-14.

4. Siddiqi KS, Husen A. Fabrication of metal and metal oxide nanoparticles by algae and their toxic effects. Nano Res Lett. 2016;11:363.

5. Siddiqi KS, Husen A. Fabrication of metal nanoparticles from fungi and metal salts: scope and application. Nano Res Lett. 2016;11:98.

6. Philip D, Unni C, Aromal SA, Vidhu VK. Murraya koenigii leaf-assisted rapid green synthesis of silver and gold nanoparticles. Spectrochem Acta A Mol Biomol Spectrosc. 2011;78:899-904.

7. Banerjee P, Satapathy M, Mukhopahayay A, Das P. Leaf extract mediated green synthesis of silver nanoparticles from widely available Indian plants: synthesis, characterization, antimicrobial property and toxicity analysis. Bioresour Bioprocess. 2014;1:3.

8. Nagar N, Jain S, Kachhawah P, Devra V. Synthesis and characterization of silver nanoparticles via green route. Korean J Chem Eng. 2016;33:2990-7.

9. Husen A. Gold nanoparticles from plant system: synthesis, characterization and their application. In: Ghorbanpour M, Manika K, Varma A, editors. Nanoscience and Plant-Soil Systems. Soil Biology. Cham: Springer, 2017;48: 455-479.
10. Siddiqi KS, Husen A. Recent advances in plant-mediated engineered gold nanoparticles and their application in biological system. J Trace Elements Med Biol. 2017:40:10-23.

11. Siddiqi KS, Rashid M, Rahman A, Tajuddin HA, Rehman S. Biogenic fabrication and characterization of silver nanoparticles using aqueousethanolic extract of lichen (Usnea longissima) and their antimicrobial activity. Biomat Res. 2018;22:23.

12. Siddiqi KS, Rashid M, Tajuddin RS, Husen A. Synthesis of silver nanoparticles using aqueous leaf extract of Diospyros montana Roxb. And their antimicrobial activity against some clinical isolates. BioNanoSci. 2019;9:30212.

13. Umer A, Naveed S, Ramzan N, Rafiqui MS. Selection of a suitable method for the synthesis of copper nanoparticles. Nano. 2012;7:1230005.

14. Jain S, Jain A, Kachhawah P, Devra V. Synthesis and size control of copper nanoparticles and their catalytic application. Trans Nonferrous Met Soc China. 2015;25:3995-4000.

15. Tiwari M, Jain P, Hariharapura RC, Narayanan K, Udaya BK, Udupa N, Rao JV. Biosynthesis of copper nanoparticles using copper-resistant Bacillus cereus, a soil isolate. Process Biochem. 2016:51:1348-56.

16. Borkow G, Gabbay J. Copper, an ancient remedy returning to fight microbial, fungal and viral infections. Cur Chem Biol. 2009:3:272-8.

17. Zheng XG, Xu CN, Tomokiyo Y, Tanaka E, Yamada H, Soejima Y. Observation of charge stripes in cupric oxide. Phys Rev Lett. 2000;85:5170-3.

18. Ren G, Hu D, Cheng EW, Vargas-Reus MA, Reip P, Allaker RP. Characterisation of copper oxide nanoparticles for antimicrobial applications. Int J Antimicrob Agent. 2009;33:587-90.

19. Din Ml, Arshad F, Hussain Z, Mukhtar M. Green adeptness in the synthesis and stabilization of copper nanoparticles: catalytic, antibacterial, cytotoxicity, and antioxidant activities. Nano Res Lett. 2017;12:638.

20. Apostolov AT, Apostolova IN, Wesselinowa JM. Dielectric constant of multiferroic pure and doped CuO nanoparticles. Solid State Commun. 2014; 192:71-4

21. Thiruvengadam M, Chung IM, Gomathi T, Ansari MA, Khanna VG, Babu V, Rajakumar G. Synthesis, characterization and pharmacological potential of green synthesized copper nanoparticles. Bioprocess Biosyst Eng. 2019;42: 1769-77.

22. Pariona N, Mtz-Enriquez Al, Sanchez-Rangel D, Carrion G, Paraguay-Delgado F, Rosas-Saito G. Green-synthesized copper nanoparticles as a potential antifungal against plant pathogens. RSC Adv. 2019;9:18835-43.

23. Lee $Y$, Choi JR, Lee KJ, Stott NE, Kim D. Large-scale synthesis of copper nanoparticles by chemically controlled reduction for applications of inkjetprinted electronics. Nanotechnology. 2008;19:598-604.

24. Rubilar O, Rai M, Tortella G, Diez MC, Seabra AB, Durán N. Biogenic nanoparticles: copper, copper oxides, copper sulphides, complex copper nanostructures and their applications. Biotechnol Lett. 2013;35:1365-75.

25. Waser $O$, Hess M, Güntner A, Novák P, Pratsinis SE. Size controlled CuO nanoparticles for Li-ion batteries. J Power Sour. 2013;241:415-22.

26. Sharma JK, Akhtar MS, Ameen S, Srivastava P, Singh G. Green synthesis of CuO nanoparticles with leaf extract of Calotropis gigantea and its dyesensitized solar cells applications. J All Comp. 2015;632:321-5.

27. Wang $F, L i H$, Yuan $H$, Sun $Y$, Chang F, Deng $H$, Xie L, Li H. A highly sensitive gas sensor based on CuO nanoparticles synthetized via a sol-gel method. RSC Adv. 2016:6:79343-9.

28. Joshi A, Sharma A, Bachheti RK, Husen A, Mishra VK. Plant-mediated synthesis of copper oxide nanoparticles and their biological applications. In: Husen A, lqbal M, editors. Nanomaterials and Plant Potential. Cham: Springer International Publishing AG; 2019. p. 221-37.

29. Lee HJ, Song JY, Kim BS. Biological synthesis of copper nanoparticles using Magnolia kobus leaf extract and their antibacterial activity. J Chem Technol Biotechnol. 2013:88:1971-7.

30. Song JY, Jang HK, Kim BS. Biological synthesis of gold nanoparticles using Magnolia kobus and Diopyros kaki leaf extracts. Process Biochem. 2009;44: 1133-8.

31. Kulkarni V, Suryawanshi S, Kulkarni P. Biosynthesis of copper nanoparticles using aqueous extract of Eucalyptus sp. plant leaves. Curr Sci. 2015;109:255-27.

32. Nagar N, Devra V. Green synthesis and characterization of copper nanoparticles using Azadirachta indica leaves. Mat Chem Phys. 2018;213: 44-51.

33. Brumbaugh AD, Cohen KA, Angelo SKS. Ultrasmall copper nanoparticles synthesized with a plant tea reducing agent. ACS Sustain Chem Eng. 2014;2: 1933-9. 
34. Pileni MP, Lisiecki I. Nanometer metallic copper particle synthesis in reverse micelles. Colloids Surf A Physicochem Eng Asp. 1993;80:63-8.

35. Singh M, Sinha I, Premkumar M, Singh AK, Mandal RK. Structural and surface plasmon behavior of cu nanoparticles using different stabilizers. Colloid Surf A. 2010;359:88-94.

36. Vazquez-Vazquez C, Banobre-Lopez M, Mitra A, Arturo Lopez-Quintela M, Rivas J. Synthesis of small atomic copper clusters in microemulsions. Langmuir. 2009;25:8208-16.

37. Narayanan KB, Sakthivel N. Coriander leaf mediated biosynthesis of gold nanoparticles. Mater Lett. 2008;62:4588-90.

38. Sheny DS, Mathew J, Philip D. Phytosynthesis of au, Ag and au-Ag bimetallic nanoparticles using aqueous extract and dried leaf of Anacardium occidentale. Spectrochim Acta Part A. 2011;79:254-62.

39. Yu W, Xie H, Chen L, Li Y, Zhang C. Synthesis and characterization of monodispersed copper colloids in polar solvents. Nano Res Lett. 2009;4: 465-70.

40. Engels $V$, Benaskar $F$, Jefferson DA, Johnson BFG, Wheatley AEH. Nanoparticulate copper - routes towards oxidative stability. Dalton Trans. 2010;39:6496-502.

41. Zhang Y, Zhu P, Li G, Zhao T, Fu X, Sun R, Zhou F, Wong C. Facile preparation of monodisperse, impurity-free, and antioxidation copper nanoparticles on a large scale for application in conductive ink. ACS Appl Mater Interf. 2014;6:560-7.

42. Cheirmadurai K, Biswas S, Murali R, Thanikaivelan P. Green synthesis of copper nanoparticles and conducting nanobiocomposites using plant and animal sources. RSC Adv. 2016;4:19507-11.

43. Wang $Y$, Biradar AV, Wang G, Sharma KK, Duncan CT, Rangan S, Asefa T. Controlled synthesis of water-dispersible faceted crystalline copper nanoparticles and their catalytic properties. Chemistry. 2010;16:10735-43.

44. Demirskyi D, Agrawal D, Ragulya A. Neck formation between copper spherical particles under single-mode and multimode microwave sintering. Mat Sci Eng: A. 2010;A527:2142-5.

45. Swarnkar RK, Singh SC, Gopal R. Effect of aging on copper nanoparticles synthesized by pulsed laser ablation in water: structural and optical characterizations. Bull Mater Sci. 2011;34:1363-9.

46. Shende S, Ingle AP, Gade A, Rai M. Green synthesis of copper nanoparticles by Citrus medica Linn. (Idilimbu) juice and its antimicrobial activity. World J Microbiol Biotechnol. 2015:31:865-73.

47. Sastry ABS, Aamanchi RBK, Rama Linga Prasad CS, Murty BS. Large-scale green synthesis of cu nanoparticles. Environ Chem Lett. 2013;11:183-7.

48. Hirai H, Wakabayashi H, Komiyama M. Preparation of polymer-protected colloidal dispersions of copper. Bull Chem Soc Japan. 1986;59:367-72.

49. Zhu YJ, Qian YT, Zhang MW, Chen ZY, Xu DF. Preparation and characterization of nanocrystalline powders of cuprous oxide by using Cradiation. Mater Res Bull. 1994;29:377-83.

50. Nasrollahzadeh M, Sajadi SM, Khalaj M. Green synthesis of copper nanoparticles using aqueous extract of the leaves of Euphorbia esula $L$ and their catalytic activity for ligand-free Ullmanncoupling reaction and reduction of 4-nitrophenol. RSC Adv. 2014:4:47313-8.

51. Kaur P, Thakur R, Chaudhury A. Biogenesis of copper nanoparticles using peel extract of Punica granatum and their antimicrobial activity against opportunistic pathogens. Green Chem Lett Rev. 2016;9:33-8.

52. Hashemipour $H$, Zadeh ME, Pourakbari R, Rahimi P. Investigation on synthesis and size control of copper nanoparticle via electrochemical and chemical reduction method. Int J Phys Sci. 2011;6:4331-6.

53. Ashfaq M, Verma $N$, Khan S. Carbon nanofibers as a micronutrient carrier in plants: efficient translocation and controlled release of cu nanoparticles. Environ Sci: Nano. 2017:4:138-48.

54. Padil WT, Černík M. Green synthesis of copper oxide nanoparticles using gum karaya as a biotemplate and their antibacterial application. Int J Nanomedicine. 2013;8:889-98.

55. Das D, Nath BC, Phukon P, Dolui SK. Synthesis and evaluation of antioxidant and antibacterial behavior of CuO nanoparticles. Coll Surf B Biointerf. 2013; 101:430-3.

56. Abboud Y, Saffaj T, Chagraoui A, El Bouari A, Brouzi K, Tanane O, Ihssane B. Biosynthesis, characterization and antimicrobial activity of copper oxide nanoparticles (CONPs) produced using brown alga extract (Bifurcaria bifurcata). Appl Nanosci. 2014;4:571-6.

57. Krithiga N, Jayachitra A, Rajalakshmi A. Synthesis, characterization and analysis of the effect of copper oxide nanoparticles in biological systems. Ind J Nano Sci. 2013;1:6-15.
58. Borgohain K, Murase N, Mahamuni S. Synthesis and properties of $\mathrm{Cu}_{2} \mathrm{O}$ quantum particles. J Appl Phys. 2002;92:1292-7.

59. Yin M, Wu CK, Lou Y, Burda C, Koberstein JT, Zhu Y, O'Brien S. Copper oxide nanocrystals. J Am Chem Soc. 2005;127:9506-11.

60. Rahman A, Ismail A, Jumbianti D, Magdalena S, Sudrajat H. Synthesis of copper oxide nanoparticles by using Phormidium cyanobacterium. Indo J Chem. 2009;9:355-60.

61. Kiruba Daniel SCG, Nehru K, Sivakumar M. Rapid biosynthesis of silver nanoparticles using Eichornia crassipes and its antibacterial activity. Curr Nanosci. 2012;8:1-5.

62. Vijay Kumar PPN, Shameem U, Kollu P, Kalyani RL, Pammi SVN. Green synthesis of copper oxide nanoparticles using Aloe vera leaf extract and its antibacterial activity against fish bacterial pathogens. BioNanoSci. 2015;5: 135-9.

63. Vishveshvar K, Aravind Krishnan MV, Haribabu K, Vishnuprasad S. Green synthesis of copper oxide nanoparticles using Ixiro coccinea plant leaves and its characterization. BioNanoSci. 2018:8:554-8.

64. Vasantharaj S, Sathiyavimal S, Saravanan M, Senthilkumar P, Kavitha G, Shanmugavel M, Manikandan E, Pugazhendhi A. Synthesis of ecofriendly copper oxide nanoparticles for fabrication over textile fabrics: characterization of antibacterial activity and dye degradation potential. J Photochem Photobiol B Biol. 2018;191:149.

65. Singh J, Kumar V, Kim KH, Rawat M. Biogenic synthesis of copper oxide nanoparticles using plant extract and its prodigious potential for photocatalytic degradation of dyes. Environ Res. 2019;177:108569.

66. Vanathi P, Rajiv P, Sivaraj R. Synthesis and characterization of Eichhorniamediated copper oxide nanoparticles and assessing their antifungal activity against plant pathogens. Bull Mater Sci. 2016;39:1165-70.

67. Ghidan AY, Al-Antary TM, Awwad AM. Green synthesis of copper oxide nanoparticles using Punica granatum peels extract: effect on green peach aphid. Environ Nanotechnol Monit Manag. 2016;6:95-8.

68. Sivaraj R, Rahman PK, Rajiv P, Salam HA, Venckatesh R. Biogenic copper oxide nanoparticles synthesis using Tabernaemontana divaricate leaf extract and its antibacterial activity against urinary tract pathogen. Spectrochim Acta A Mol Biomol Spectrosc. 2014;133:178-81.

69. Huang J, Li Q, Sun D, Lu Y, Su Y, Yang X, Wang H, Wang Y, Shao W, He N, Hong J, Chen C. Biosynthesis of silver and gold nanoparticles by novel sun dried Cinnamomum camphora leaf. Nanotechnology. 2007;18:105104-15.

70. Gopinath V, Priyadarshini S, Al-Maleki AR, Alagiri M, Yahya R, Saravanan S, Vadivelu J. In vitro toxicity, apoptosis and antimicrobial effects of phytomediated copper oxide nanoparticles. RSC Adv. 2016;6:110986-95.

71. Saif S, Tahir A, Asim T, Chen Y. Plant mediated green synthesis of CuO nanoparticles: comparison of toxicity of engineered and plant mediated CuO nanoparticles towards Daphnia magna. Nanomaterials. 2016;6:205.

72. Odzak N, Kistler D, Behra R, Sigg L. Dissolution of metal and metal oxide nanoparticles in aqueous media. Environ Pollut. 2014;191:132-8.

73. Adam N, Leroux F, Knapen D, Bals S, Blust R. The uptake of ZnO and CuO nanoparticles in the water-flea Daphnia magna under acute exposure scenarios. Environ Pollut. 2014;194:130-7.

74. Regier N, Cosio C, von Moos N, Slaveykova VI. Effects of copper-oxide nanoparticles, dissolved copper and ultraviolet radiation on copper bioaccumulation, photosynthesis and oxidative stress in the aquatic macrophyte Elodea nuttallii. Chemosphere. 2015;128:56-61.

75. Perreault F, Oukarroum A, Melegari SP, Matias WG, Popovic R. Polymer coating of copper oxide nanoparticles increases nanoparticles uptake and toxicity in the green alga Chlamydomonas reinhardtii. Chemosphere. 2012; 87:1388-94.

76. Shi J, Abid AD, Kennedy IM, Hristova KR, Silk WK. To duckweeds (Landoltia punctata), nanoparticulate copper oxide is more inhibitory than the soluble copper in the bulk solution. Environ Pollut. 2011;159:1277-82.

77. Raja Naika H, Lingaraju K, Manjunath K, Kumar D, Nagaraju G, Suresh D, Nagabhushana H. Green synthesis of $\mathrm{CuO}$ nanoparticles using Gloriosa superba L. extract and their antibacterial activity. J Taibah Univ Sci. 2015;9:7-12.

78. Sankar R, Manikandan P, Malarvizhi V, Fathima T, Shivashangari KS, Ravikumar V. Green synthesis of colloidal copper oxide nanoparticles using Carica papaya and its application in photocatalytic dye degradation. Spectrochim Acta A Mol Biomol Spectrosc. 2014;121:746-50.

79. Ethiraj AS, Kang DJ. Synthesis and characterization of CuO nanowires by a simple wet chemical method. Nano Res Lett. 2012;7:70.

80. Nasrollahzadeh M, Maham M, Sajadi SM. Green synthesis of CuO nanoparticles by aqueous extract of Gundelia tournefortii and evaluation of 
their catalytic activity for the synthesis of N-monosubstituted ureas and reduction of 4-nitrophenol. J Colloid Interface Sci. 2015;455:245-53.

81. Adzet T, Puigmacia M. High-performance liquid chromatography of caffeoylquinic acid derivatives of Cynara scolymus L. leaves. J Chromatograph A. 1985;348:447-53.

82. Haghi G, Hatami A, Arshi R. Distribution of caffeic acid derivatives in Gundelia tournefortii L. Food Chem. 2011;124:1029-35.

83. Nasrollahzadeh M, Mohammad Sajadi S, Rostami-Vartooni A. Green synthesis of CuO nanoparticles by aqueous extract of Anthemis nobilis flowers and their catalytic activity for the $\mathrm{A}^{3}$ coupling reaction. J Colloid Interface Sci. 2015;459:183-8.

84. Ullah H, Ullah Z, Fazal A, Irfan M. Use of vegetable waste extracts for controlling microstructure of $\mathrm{CuO}$ nanoparticles: green synthesis, characterization, and photocatalytic applications. J Chem. 2017;2721798:5.

85. Ranjbar-Karimi R, Bazmandegan-Shamili A, Aslani A, Kaviani K. Sonochemical synthesis, characterization and thermal and optical analysis of CuO nanoparticles. Phys B Condens Matter. 2010;405:3096-100.

86. Nasrollahzadeh M, Sajadi SM, Rostami-Vartooni A, Bagherzadeh M. Green synthesis of $\mathrm{Pd} / \mathrm{CuO}$ nanoparticles by Theobroma cacao L. seeds extract and their catalytic performance for the reduction of 4-nitrophenol and phosphine-free heck coupling reaction under aerobic conditions. J Colloid Interface Sci. 2015;448:106-13.

87. Geil P, Anderson J. Nutrition and health implications of dry beans: a review. J Am Coll Nutr. 1994;13:549-58.

88. Mishra SB, Rao CV, Ojha SK, Vijayakumar M, Verma A. An analytical review of plants for anti diabetic activity with their phytoconstituent and mechanism of action: a review. Int J Pharmacol Sci Res. 2010;1:29-44.

89. Bachheti A, Sharma A, Bachheti RK, Husen A, Pandey DP. Plant allelochemicals and their various application. In: Mérillon JM, Ramawat KG, editors. Co-Evolution of Secondary Metabolites, Reference Series in Phytochemistry. Cham: Springer International Publishing AG. https://doi.org/ 10.1007/978-3-319-76887-8_14-1 (2019).

90. Nagajyothi PC, Muthuraman P, Sreekanth TVM, Kim DH, Shim J. Green synthesis: in-vitro anticancer activity of copper oxide nanoparticles against human cervical carcinoma cells. Arab J Chem. 2017;10:215-25.

91. Bawadi HA. Inhibition of Caco-2 colon, MCF-7, and Hs578T breast, and DU 145 prostatic cancer cell proliferation by water soluble black bean condensed tannins. Can Lett. 2005;218:153-62.

92. Bobe G, Barret KG, Mentor-Marcel RA, Saffiotti U, Young MR, Colburn NH, Albert PS, Bennink MR, Lanza E. Dietary cooked navy beans and their fractions attenuate colon carcinogenesis in azoxymethane-induced Ob/Ob mice. Nutri Cancer. 2008;60:373-81.

93. Hangen L, Bennik MR. Consumption of black beans and navy beans (Phaseolus vulgaris) reduced azoxymethane-induced colon cancer in rats. Nutr Cancer. 2002;44:60-5.

94. Thompson MD, Mensack MM, Jiang W, Zhu Z, Lewis MR, McGinley JN, Brick MA, Thompson HJ. Cell signaling pathways associated with a reduction in mammary cancer burden by dietary common bean (Phaseolus vulgaris L.). Carcinogenesis. 2012;33:226-32.

95. Mukhopadhyay R, Kazi J, Debnath MC. Synthesis and characterization of copper nanoparticles stabilized with Quisqualis indica extract: evaluation of its cytotoxicity and apoptosis in B16F10 melanoma cells. Biomed Pharmacother. 2018;97:1373-85.

96. Khani R, Roostaei B, Bagherzade G, Moudi M. Green synthesis of copper nanoparticles by fruit extract of Ziziphus spina-christi (L.) Willd.: application for adsorption of triphenylmethane dye and antibacterial assay. J Mol Liq. 2018:255:541-9.

97. Machado TDB, Leal ICR, Amaral ACF, Dos Santos KRN, Da Silva MG, Kuster RM. Antimicrobial Ellagitannin of Punica granatum Fruits. J Braz Chem Soc. 2002;13:606-10

98. Voravuthikunchai SP, Sririrak T, Limsuwan S, Supawita T, lida T, Honda T. Inhibitory effects of active compounds from Punica granatum pericarp on Verocytotoxin production by Enterohemorrhagic Escherichia coli O157: H7. J Health Sci. 2005:51:590-6.

99. Naz S, Siddiqi R, Ahmad S, Rasool SA, Sayeed SAJ. Antibacterial activity directed isolation of compounds from Punica granatum. J Food Sci. 2007;72:341-5.

100. Azam A, Ahmed AS, Oves M, Khan MS, Memic A. Size-dependent antimicrobial properties of $\mathrm{CuO}$ nanoparticles against gram-positive and -negative bacterial strains. Int J Nanomedicine. 2012;7:3527-35.

101. Nasrollahzadeh M, Maham M, Rostami-Vartooni A, Bagherzadeh M, Sajadi SM. Barberry fruit extract assisted in situ green synthesis of $\mathrm{cu}$ nanoparticles supported on a reduced graphene oxide- $\mathrm{Fe}_{3} \mathrm{O}_{4}$ nanocomposite as a magnetically separable and reusable catalyst for the O-arylation of phenols with aryl halides under ligand-free conditions. RSC Adv. 2015:5:64769-80.

102. Getnet Z, Husen A, Fetene M, Yemata G. Growth, water status, physiological, biochemical and yield response of stay green sorghum \{Sorghum bicolor (L.) Moench\} varieties-a field trial under drought-prone area in Amhara regional state, Ethiopia. J Agron. 2015;14:188-202.

103. Embiale A, Hussein M, Husen A, Sahile S, Mohammed K. Differential sensitivity of Pisum sativum L. cultivars to water-deficit stress: changes in growth, water status, chlorophyll fluorescence and gas exchange attributes. J Agron. 2016;15:45-57.

104. Siddiqi KS, Husen A. Engineered gold nanoparticles and plant adaptation potential. Nano Res Lett. 2016;11:400.

105. Siddiqi KS, Husen A. Plant response to engineered metal oxide nanoparticles. Nano Res Lett. 2017;12:92.

106. Husen A, labal M, Aref IM. Plant growth and foliar characteristics of faba bean (Vicia faba L.) as affected by indole-acetic acid under water-sufficient and water-deficient conditions. J Environ Biol. 2017;38:179-86.

107. Husen A, lqbal M, Sohrab SS, Ansari MKA. Salicylic acid alleviates salinitycaused damage to foliar functions, plant growth and antioxidant system in Ethiopian mustard (Brassica carinata A. Br.). Agri Food Sec. 2018;7:44.

108. Husen A, Iqbal M, Khanum N, Aref IM, Sohrab SS, Meshresa G. Modulation of salt-stress tolerance of Niger (Guizotia abyssinica), an oilseed plant, by application of salicylic acid. J Environ Biol. 2019;40:94-104.

109. Dimkpa CO, McLean JE, Latta DE, Manangon E, Britt DW, Johnson WP, Boyanov MI, Anderson AJ. CuO and ZnO nanoparticles: phtotoxicity, metal speciation, and induction of oxidative stress in sand-grown wheat. J Nanopart Res. 2012;14:1125-9.

110. Pradhan SP, Patra S, Das S, Chandra S, Mitra KK, Dey S, Akbar P, Palit A, Goswani A. Photochemical modulation of biosafe manganese nanoparticles on Vigna radiata: a detailed molecular, biochemical, and biophysical study. Environ Sci Technol. 2013;47:13122-31.

111. Yasmeen F, Raja NI, Razzaq A, Komatsu S. Proteomic and physiological analyses of wheat seeds exposed to copper and iron nanoparticles. Biochim Biophys Acta. 1865:2017:28-42.

112. Ashfaq M, Singh S, Sharma A, Verma N. Cytotoxic evaluation of the hierarchical web of carbon micronanofibers. Ind Eng Chem Res. 2013;52: 4672-82.

113. Nair PMG, Chung IM. Impact of copper oxide nanoparticles exposure on Arabidopsis thaliana growth, root system development, root lignificaion, and molecular level changes. Environ Sci Pollut Res. 2014;21:12709-22.

114. Lequeux H, Hermans C, Lutts S, Nathalie V. Response to copper excess in Arabidopsis thaliana: impact on the root system architecture, hormone distribution, lignin accumulation and mineral profile. Plant Physiol Biochem. 2010;48:673-82.

115. Husen A. Growth characteristics, physiological and metabolic responses of teak (Tectona grandis Linn. F.) clones differing in rejuvenation capacity subjected to drought stress. Silvae Gene. 2010;59:124-36

116. Chung IM, Rekha K, Venkidasamy B, Thiruvengadam M. Effect of copper oxide nanoparticles on the physiology, bioactive molecules, and transcriptional changes in Brassica rapa ssp. rapa seedlings. Water Air Soil Pollut. 2019;230:48.

117. Karlsson HL, Cronholm P, Gustafsson J, Moller L. Copper oxide nanoparticles are highly toxic: a comparison between metal oxide nanoparticles and carbon nanotubes. Chem Res Toxicol. 2008;21:1726-32.

118. Heinlaan M, Ivask A, Blinova I, Dubourguier HC, Kahru A. Toxicity of nanosized and bulk $\mathrm{ZnO}, \mathrm{CuO}$ and $\mathrm{TiO}_{2}$ to bacteria Vibrio fischeri and crustaceans Daphnia magna and Thamnocephalus platyurus. Chemosphere. 2008;71:1308-16.

119. Tavares KP, Caloto-Oliveira Á, Vicentini DS, Melegari SP, Matias WG, Barbosa S, Kummrow F. Acute toxicity of copper and chromium oxide nanoparticles to Daphnia similis. Ecotoxicol Environ Contam. 2014;9:43-50.

120. Adam N, Vakurov A, Knapen D, Blust R. The chronic toxicity of CuO nanoparticles and copper salt to Daphnia magna. J Hazard Mater. 2015; 283:416-22.

121. Rajeshkumar S, Menon S, Venkat Kumar S, Tambuwala MM, Bakshi HA, Mehta M, Satija S, Gupta G, Chellappan DK, Thangavelu L, Dua K. Antibacterial and antioxidant potential of biosynthesized copper nanoparticles mediated through Cissus arnotiana plant extract. J Photochem Photobiol B. 2019;197:111531. 
122. Asghar MA, Zahir E, Shahid SM, Khan MN, Asghar MA, lqbal J, Walker G. Iron, copper and silver nanoparticles: green synthesis using green and black tea leaves extracts and evaluation of antibacterial, antifungal and aflatoxin B1 adsorption activity. LWT. 2018;90:98-107.

123. Roy K, Ghosh CK, Sarkar CK. Rapid detection of hazardous $\mathrm{H}_{2} \mathrm{O}_{2}$ by biogenic copper nanoparticles synthesized using Eichhornia crassipes extract. Microsyst Technol. 2019;25:1699-703.

124. Zangeneh MM, Ghaneialvar H, Akbaribazm H, Ghanimatdan M, Abbasi N, Goorani S, Pirabbasi E, Zangeneh A. Novel synthesis of Falcaria vulgaris leaf extract conjugated copper nanoparticles with potent cytotoxicity, antioxidant, antifungal, antibacterial, and cutaneous wound healing activities under in vitro and in vivo condition. J Photochem Photobiol B Biol. 2019;197:111556.

125. Rajeshkumar S, Rinith G. Nanostructural characterization of antimicrobial and antioxidant copper nanoparticles synthesized using novel Persea americana seeds. OpenNano. 2018:3:18-27.

126. Kerour A, Boudjadar S, Bourzami R, Allouche B. Eco-friendly synthesis of cuprous oxide $\left(\mathrm{Cu}_{2} \mathrm{O}\right)$ nanoparticles and improvement of their solar photocatalytic activities. J Solid State Chem. 2018:263:79-83.

127. Mehr ES, Sorbiun M, Ramazani A, Fardood ST. Plant-mediated synthesis of zinc oxide and copper oxide nanoparticles by using Ferulago angulata (Schlecht) Boiss extract and comparison of their photocatalytic degradation of Rhodamine B (RhB) under visible light irradiation. J Mater Sci Mater Electron. 2018;29:1333-40

128. Dobrucka R. Antioxidant and catalytic activity of biosynthesized CuO nanoparticles using extract of Galeopsidis herba. J Inorg Organomet Polym Mat. 2018;28:812-9.

129. Jadhav MS, Kulkarni S, Raikar P, Barretto DA, Vootla SK, Raikar US. Green biosynthesis of $\mathrm{CuO} \& \mathrm{Ag}-\mathrm{CuO}$ nanoparticles from Malus domestica leaf extract and evaluation of antibacterial, antioxidant and DNA cleavage activities. New J Chem. 2018;42:204-13.

130. Khatami M, Varma RS, Heydari M, Peydayesh M, Sedighi A, Askari HA, Rohani M, Baniasadi M, Arkia S, Seyedi F, Khatami S. Copper oxide nanoparticles greener synthesis using tea and its antifungal efficiency on Fusarium solani. Geomicrobiol J. 2019;36:777-81.

131. Akhter SMH, Mohammad F, Ahmad S. Terminalia belerica mediated green synthesis of nanoparticles of copper, iron and zinc metal oxides as the alternate antibacterial agents against some common pathogens. BioNanoSci. 2019:9:365-72.

\section{Publisher's Note}

Springer Nature remains neutral with regard to jurisdictional claims in published maps and institutional affiliations.

Ready to submit your research? Choose BMC and benefit from:

- fast, convenient online submission

- thorough peer review by experienced researchers in your field

- rapid publication on acceptance

- support for research data, including large and complex data types

- gold Open Access which fosters wider collaboration and increased citations

- maximum visibility for your research: over $100 \mathrm{M}$ website views per year

At $\mathrm{BMC}$, research is always in progress.

Learn more biomedcentral.com/submissions 